\title{
Emissions from Drying in the Wood Based Board Industry
}

\author{
Uğur BİLGíN* Semra ÇOLAK Gürsel ÇOLAKOĞLU \\ Karadeniz Technical University, Faculty of Forestry, Department of Forest Engineering, Kanuni Campus, Trabzon, Turkey
}

How to cite: Bilgin, U., Çolak, S. \& Çolakoğlu, G. (2020). Emissions from drying in the wood based board industry. J. Anatolian Env. and Anim. Sciences, 5(5), 833-840.

Atıf yapmak için: Bilgin, U., Çolak, S. \& Çolakoğlu, G. (2020). Ahşap esaslı levha sektöründe kurutma kaynaklı emisyonlar. Anadolu Çev. ve Hay. Dergisi, 5(5), 833-840.

* iD: https://orcid.org/0000-0003-4056-7100
iD: https://orcid.org/0000-0003-1937-7708
iD: https://orcid.org/0000-0002-3795-281X
*Corresponding author's:
Uğur BİLGiN
Karadeniz Technical University, Department
of Forest Industry Engineering, Kanuni
Campus, Trabzon, Turkey.
M: ugurbilgin@ ktu.edu.tr
Mobile telephone: +90 (537) 7051323
Telephone : +90 (462) 3771560
Fax $\quad+90$ (462) 3257499

\begin{abstract}
The reason why wood-based boards are preferred in many areas of use, especially in furniture, is that they can be produced in desired properties and are cheap. In addition, wood defects such as different work in three dimensions, differences in resistance values, internal stresses and physical changes seen in solid wood are not encountered in wood-based boards. Volatile organic compound (VOC) emissions from wood-based panels occur from the raw materials of the boards and during production stages such as gluing, storage, pressing and drying. Most of the VOCs from wood raw materials are formed during the drying process. VOCs contribute to the formation of nitrogen oxides and photo-oxidants in the presence of sunlight. Photo-oxidants are harmful to humans as they irritate the respiratory and sensitive parts of the lungs. It also disrupts photosynthesis and damages forests and crops. The aim of this study is to evaluate the factors affecting the emissions that occur during the drying process in wood-based boards and the processes applied to reduce the emission..
\end{abstract}

Keywords: Drying process, emission of wood based panels, volatile organic compounds (VOC), wood based panels.

\section{Ahşap Esaslı Levha Sektöründe Kurutma Kaynaklı Emisyonlar}

*Sorumlu yazarın:

Uğur BILLGiN

Karadeniz Teknik Üniversitesi Orman

Fakültesi Orman Endüstri Mühendisliği

Bölümü, Kanuni Kampusü Trabzon, Türkiye

$\triangle$ : ugurbilgin@ktu.edu.tr

Cep telefonu : +90(537) 7051323

Telefon : : $+90(462) 3771560$

Faks : +90(462) 3257499
Öz: Ahşap esaslı levhaların başta mobilya olmak üzere birçok kullanım alanında tercih edilmesinin sebebi istenilen özelliklerde üretilebilmesi ve ucuz olmasıdır. Ayrıca masif odunda görülen üç boyutta farklı çalışma, direnç değerlerinde farklılıklar, iç gerilmeler ve fiziksel değişimler gibi odun kusurlarına nispeten ahşap esaslı levhalarda karşılaşılmaz. Ahşap esaslı levhalardan kaynaklanan uçucu organik bileşik (VOC) emisyonları, levhaların hammaddelerinden ve tutkallama, depolama, presleme, kurutma gibi üretim aşamalarında oluşmaktadır. Odun hammaddesinden kaynaklanan VOC ların büyük kısmı kurutma işlemi sırasında oluşur. VOC lar azot oksitlerin ve güneş ışığının varlığında foto-oksidanların oluşumuna katkıda bulunur. Foto-oksidanlar solunum yollarında ve akciğerlerin hassas kısımlarında tahrişe neden oldukları için insanlar için zararlıdır. Ayrıca fotosentezi bozar, ormanlara ve ürünlere zarar verir. Bu çalışmanın amacı ahşap esaslı levhalarda kurutma işleminde oluşan emisyonları etkileyen faktörlerin ve emisyonu düşürmek için uygulanan işlemlerin değerlendirilmesidir.

Anahtar kelimeler: Ahșap esaslı paneller, ahșap esaslı panellerden kaynaklanan emisyonlar, kurutma ișlemi, uçucu organik bilessikler.

\section{INTRODUCTION}

Due to the rapid population growth, urbanization, economic, social and cultural developments in the world, the decrease in the availability of wood raw materials and the increase in the demand for wooden products caused the importance of wood-based panels products to increase. Wood-based panels such as plywood, medium density fiberboard (MDF), particleboard and oriented particleboard are among the most widely used materials all 
over the world. These materials are widely used in the construction, decoration and furnishing of homes, offices, schools as well as other non-industrial workplaces (Bilgin, 2019; Böhm et al., 2012).

Asia-Pacific region accounted for 61 percent of global production in 2018 (248 million $\mathrm{m}^{3}$ ), followed by Europe (90 million $\mathrm{m}^{3}$, or 22 percent), Northern America (48 million $\mathrm{m}^{3}$, or 12 percent), Latin America and the Caribbean (19 million $\mathrm{m}^{3}$, or 4 percent) and Africa (3 million $\mathrm{m}^{3}$ or 1 percent). The four top consumers (China, Germany, Russia, USA) of wood-based panels are the same as the four largest producers, suggesting that the products are mostly consumed domestically. The trends in consumption are similar to those in production. The fifthlargest consumer is Poland (overtaking Turkey and Japan in 2015), where consumption increased from 9 million $\mathrm{m}^{3}$ in 2014 to 12 million $\mathrm{m}^{3}$ in 2018 (FAO, 2018).

Wood-based panel production amounts in the world between 2014-2018 are given in Figure 1.

Turkey's fiberboard industry is the highest production level in 2017. It is followed by particleboard, plywood and OSB. Wood-based panels production amounts in Turkey between the years 2010-2017 is given in Table 1.

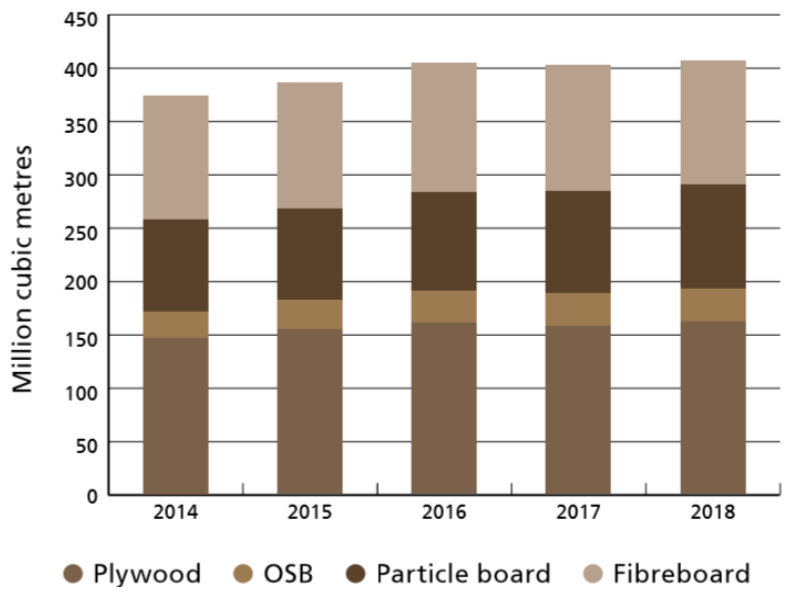

Figure 1. Wood based panel production in the World (FAO, 2018).

Table 1. Turkey forest product production $\left(100 \mathrm{~m}^{3}\right)$ (Oğuz et al., 2019).

\begin{tabular}{lccccccc}
\hline Product/Year & $\mathbf{2 0 1 1}$ & $\mathbf{2 0 1 2}$ & $\mathbf{2 0 1 3}$ & $\mathbf{2 0 1 4}$ & $\mathbf{2 0 1 5}$ & $\mathbf{2 0 1 6}$ & $\mathbf{2 0 1 7}$ \\
& & & & & & & \\
\hline Veneers & 88 & 85 & 84 & 85 & 87 & 270 & 74 \\
Plywood & 115 & 116 & 116 & 150 & 116 & 120 & 105 \\
Particle Board & 3.580 & 3.875 & 4.225 & 4.425 & 4.361 & 4.202 & 4.286 \\
OSB & 40 & 75 & 75 & 75 & 75 & 80 & 75 \\
MDF/HDF & 3.570 & 3.900 & 4.285 & 4.885 & 4.777 & 5.069 & 4.747 \\
Other Fiber Boards & 15 & 15 & 15 & 15 & 15 & 15 & 59 \\
\end{tabular}

Wood-Water Relationship: Wood is a porous material that contains air and water and wood cells. Wood loses or gains moisture depending on the environmental conditions to which it is exposed. Consequently, the weight of a piece of wood is not constant. This relationship is called moisture content and is expressed as the weight of water in the cell walls and lumen as a percentage of the weight of the oven dry (dry weight in the oven) (Walker, 2006; Rowell, 2005).

The cell wall consists of cellulosic polymers, noncellulosic carbohydrates (hemicellulose etc.) and a lignin matrix that reinforces them. If water is adsorbed to cellulose and hemicellulose in the cell wall, it is bound water. The water in the lumen of the cells is free water. Free water is only found when all areas in the cell wall are filled with water; this point is called the fiber saturation point (FSP). All water added to wood after FSP is reached is called free water. The physical and mechanical properties of the wood material are mostly related to the fiber saturation point. For example, as the moisture rises below the fiber saturation point, the strength from mechanical properties decreases (Rowell, 2005). Free and bound water are shown in Figure 2.

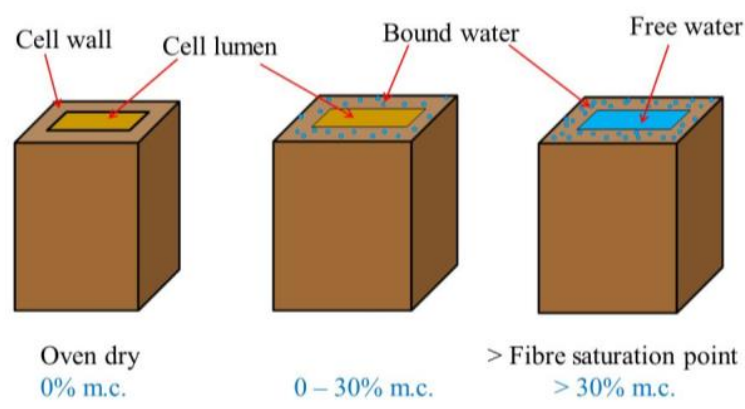

Figure 2. Water in wood (Web-1).

When drying from the green condition to the FSP (approximately 25-30\% moisture content), only free water is lost and therefore the cell wall volume does not change. However, when the wood is dried further, the water bound from the cell walls is removed and the volume of the wood begins to change (Rowell, 2005). One of the main problems encountered is that wood shrinks as it loses moisture and swells again as it regains moisture (Walker, 2006). In addition, the structure and arrangement of cellulose in the cell wall, the parallel or vertical extension of the cells to the tree axis and their symmetrical placement within the tree trunk give the wood an anisotropic structure. Since wood material is anisotropic, it shows shrinkage and swelling at different rates in three main directions (longitudinal, tangent, radial) (Nurgün and Ergin, 1997).

Wood-Based Panels: The main products produced in the wood based panel production sector are plywood(PW), particleboard (PB), medium density 
fibreboard (MDF) and oriented particleboard (OSB). Although some structural features such as usage areas and strength values of particleboard, MDF and OSB products differ from each other, they are generally produced in a continuous process that includes the following basic process steps (Figure 3) (Web-2). Plywood production process is different from the others.

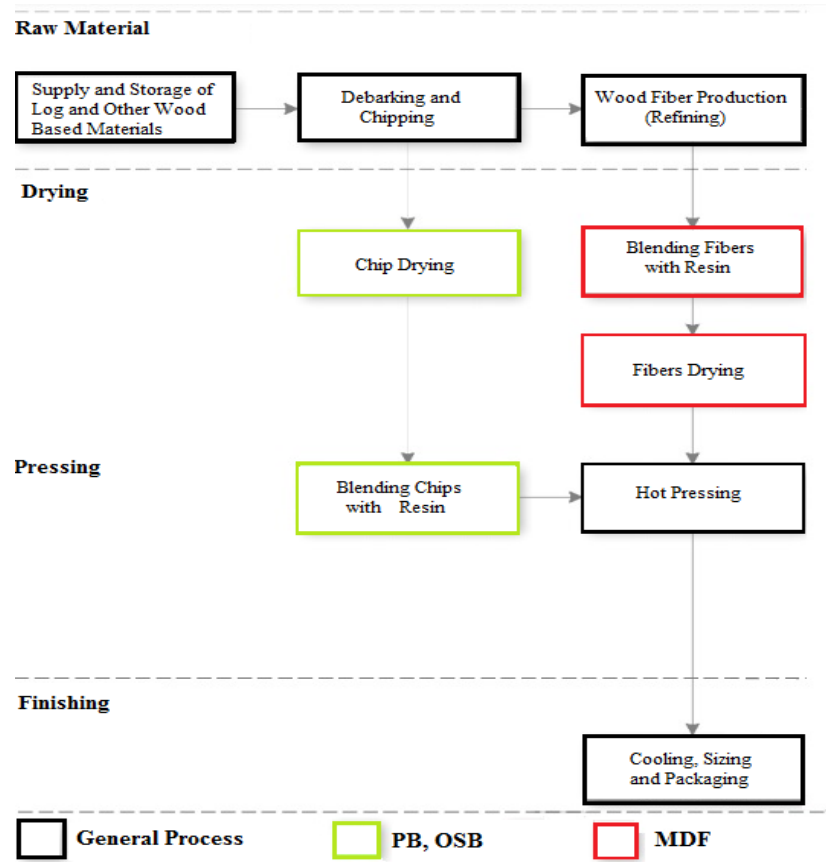

Figure 3. General process for $\mathrm{PB}, \mathrm{OSB}$ and MDF.

The drying process is very important from the wood panel production stages. Because drying is the process of removing the water (moisture) in the wood that is generally not suitable for the usage areas. The degree of dryness required in wood depending on where it will be used is very important (Altınok et al., 2009).

Drying in particleboard production: First trials on particleboard production, It was held in Europe and North America before World War II. The first particleboard factory was established in Bremen, Germany in 1941 during World War II and started commercial particleboard production. Technological and scientific studies on particleboard production have intensified after the years of World War II and the raw material shortage encountered by Germany was tried to be overcome in this way (Zengin, 2009).

Particleboard according to EN 309 standard; These are panels obtained by hot pressing of particle obtained from wood pieces (wood pieces, particle, sawdust, etc.) and / or lignocellulosic materials (from lignified plants such as flax, hemp yarn, dehydrated sugar cane pulp, etc.) (Özen and Kalaycığlu, 2008).

The process of drying the particle affects the curing time of the glue, the panel being loose or bursting. Therefore, the particles should be dried to a moisture content of $1 \%-4 \%$ in accordance with the humidity of the panel exit from the press (Şahin, 2018).

Drying in fiberboard production: Although the first appearance of the fiberboard industry can go back to the early 1900s, large-scale commercial production only emerged between the second world wars and in the United States. The first fiberboard production factory was established in Great Britain in 1898, followed by factories established in New Jersey (United States of America) in 1908 and in Canada in 1909. The first equipped fiberboard factory was established in Mississippi in 1926 (Zengin, 2009).

Fiberboard; It is a product obtained by drying or pressing the panel draft created by using the natural adhesion and felting properties of vegetable fibers and fiber bundles or by using additional adhesive material. Briefly; It is a type of panel obtained by reshaping the fiber and fiber bundles formed by fibrillation of lignocellulosic materials (Eroğlu and Usta, 2000).

Before the drying process, the fibers are brought to a consistency that can be pumped with pumps with the addition of water and resin and directed to the dryer. The moisture of the fibers entering the dryer is around $50 \%$, and this moisture should decrease to a value between $6-12 \%$. If sufficient drying is not provided, steam exits from the panel by explosion (Eroğlu and Usta, 2000). If the fibers are dried for more than 7 seconds, there is a risk of fire (Önem, 2018).

Drying in OSB production: Particle board making from oriented particles is based on the work of Armin Elmendorf in the USA and Wilhelm Klauditz in Germany in the late 1940s and early 1950s. Generally, two OSB standards are used. OSB3 of these is produced for use in exterior and moisture resistant places. OSB2, on the other hand, is produced for use in interior and places requiring less moisture resistance (Çakmak, 2018).

OSB; It is a panel-shaped material produced by pressing the draft under temperature and pressure obtained by mixing specially prepared particles with a suitable glue and directing them in the desired direction during laying (Akbulut et al., 2002).

The moisture content of the particles to be used for OSB production should be around $2-5 \%$ after drying. The particle moisture content affects the panel resistance properties, panel pressing factor, glue consumption amount and the physical properties of the panel (Doğan, 2015).

Drying in plywood production: Veneer and plywood date back to the times of the pharaohs. It is stated that the first wood veneer panel was produced in Egypt 3000 years ago. Plywood obtained from veneers was used in king and prince furniture and coffins. The first machine that will constitute the basis of today's rotary-cut veneer machines in Europe was built in 1818 (Çolakoğlu, 2004). 
Plywood according to EN 313-2; It is defined as a woodbased panel consisting of layers that are glued on each other with the fiber direction generally perpendicular. Layers defined as veneer are thin boards at most $7 \mathrm{~mm}$ thick obtained by peeling, cutting or sawn from wood (Çolakoğlu, 2004). Plywood production is shown in Figure 4.
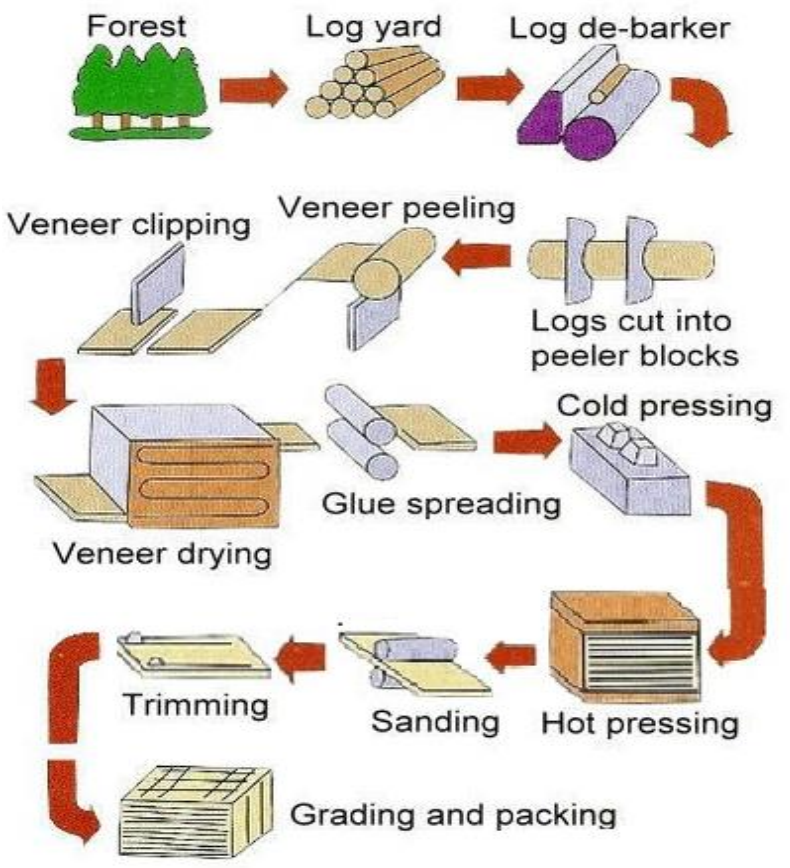

Figure 4. Plywood production (Bilgin, 2019).

Veneer drying is an important step in the manufacture of wood-based panel products such as plywood and laminated veneer lumber (LVL). If the wet veneers from the peeling and cutting machines are not dried immediately, undesirable color changes may occur due to the effect of fungi and chemical reactions (Çolakoğlu, 2004). The purpose of veneer drying is to reduce the moisture content to a suitable range for bonding plywood and other veneer-produced materials. The veneers are dried to an average moisture content of $3 \%$ in the manufacturing process because the moisture content of all veneers must be below $7 \%$ before bonding. High drying temperatures in the veneer production process are effective on both physical and mechanical properties of plywood (Aydin and Çolakoğlu, 2005).

\section{VOLATILE ORGANIC COMPOUNDS (VOC)}

In the recent past, both wood and wood products, especially wood-based panels, have become environmental problems. Volatile organic compounds (VOCs) released from wood-based panels are harmful to humans when they cause irritation to the respiratory tract and parts of the lungs (Granström, 2005). In addition, wood and wood-based panels are one of the 10 most concentrated VOCs in office buildings, and these products cause poor air quality in buildings (Yu et al., 2010).

VOCs can be classified into several types based on their chemical structure (alkanes, aromatic hydrocarbons, aldehydes, etc.), physical properties (boiling point, vapor pressure), or potential health effects (irritant, carcinogenic or neurotoxic), (Da Silva, 2017). The World Health Organization (WHO) defines a VOC as any compound with a boiling point between $50-100^{\circ} \mathrm{C}$ and $240-260^{\circ} \mathrm{C}$ and having a saturated vapor pressure of more than $100 \mathrm{kPa}$ at $25^{\circ} \mathrm{C}$ ( WHO, 2010). VOCs can be found in vapor, liquid or solid form at room temperature (Burn et al., 1993). The World Health Organization has classified organic pollutants according to their boiling points into three types and summarized in Table 2.

Table 2. Classification of VOC (Da Silva, 2017).

\begin{tabular}{ll}
\hline Type & Boiling point $\left({ }^{\circ} \mathbf{C}\right)$ \\
\hline Very Volatile Organic Compound & $<0$ to $50-100$ \\
Volatile Organic Compound & $50-100$ to $240-260$ \\
Semi - Volatile Organic Compound & $240-260$ to $380-400$ \\
\hline
\end{tabular}

Oxidation of VOCs generally results in formaldehyde formation (WHO, 2010). Ozone can easily oxidize naturally occurring terpenes in the air, leading to the formation of simple aldehydes such as formaldehyde (Stefanowski, 2018). Some reports have mentioned that formaldehyde emission arises from wood during hot pressing of wood-based panels, but it is considered to have an insignificant contribution to the formaldehyde emission level (Böhm et al., 2012). In addition, Çolakoğlu et al. (2002) investigated the effect of waiting times of veneers before drying on formaldehyde emission. Immediately after the production, it has performed the drying process by waiting 1 week, 2 weeks and 1 month. No significant difference was found between formaldehyde emissions.

There are numerous sources of both VOCs and formaldehyde. Volatile organic compounds (VOCs) are found in all natural and synthetic materials, from gasoline to flowers, water to wine. The uses of these versatile compounds are numerous (Burn et al., 1993). Natural materials also emit different amounts of formaldehyde; It is known to produce meat $(2-20 \mathrm{mg} \mathrm{kg} \mathrm{1)}$, fruits and vegetables (6.3-35 mg kg 1) wood (0.04 mg kg 1) and even volcanoes (WHO, 2010). It is also a product of human metabolism and can be detected in human breath at levels ranging from 1.2 to $72 \mathrm{ppb}$ (Stefanowski, 2018).

VOC from Wood: The cell wall of wood consists of carbohydrate (cellulose and hemicellulose), lignin and extractive substances. A significant portion of wood extractives are volatile organic compounds (VOCs) consisting of terpenes, terpenoids, flavonoids, alcohols, 
aldehydes and ketones. It also contains small to large alkenes and fatty acids (Adamová et al., 2020).

Wood VOC emissions can be divided into primary and secondary VOC emissions. Primary VOCs are free, unbound volatile compounds, such as terpenes, initially found in high concentrations in wood due to their biological functions in trees. On the other hand, secondary VOCs, including hexanal, pentanal, and acetic acid, are composed of chemically or physically bonded compounds released by chemical (egoxidation, hydrolysis) or physical (eg mechanical corrosion) degradation of wood or wood extractives (Pohleven et al. , 2019). Table 3 indicates the most abundant VOCs emitted from different trees.

Table 3. A group of the most abundant VOCs emitted from different tree species, containing VOC concentrations emitted from sapwood / heartwood on day 31 (Adamová et al., 2020).

\begin{tabular}{ll}
\hline Extractive/Group of VOCs & \multicolumn{1}{c}{ VOC } \\
\hline Terpenes & $\alpha$-pinene, $\beta$-pinene, Camphene, $\Delta 3$-carene, Limonene \\
& Benzaldehyde, Decanal, Furfural, Hexanal, Nonanal, \\
Aldehydes & Octanal, Pentanal, Formaldehyde \\
Acids & Acetic acid \\
\hline
\end{tabular}

VOC emissions can be significantly affected by the raw materials and production techniques of the panels. VOC emission may occur as a result of oxidation, thermolysis or evaporation in plate production stages such as storage, drying and pressing (Çolak, 2002). Almost all of the VOCs generated during the drying process are caused by the wood itself. Most of the VOCs formed during the pressing process are caused by the glue.

Drying Process: VOC emission in the drying of the panels is caused by factors such as wood species, drying type, dryer, temperature and time (Velic et al., 2019; Çolak, 2002).

Wood species: VOC emissions from hardwoods are significantly lower than softwoods because they do not contain and emit volatile terpenes. Hardwood VOCs are mainly degradation products resulting from the thermal breakdown of wood tissue, including lignin, cellulose, hemicellulose and extractives (Banerjee et al., 1995). Mono-, di-, and sesquiterpenes are the predominant VOCs for softwoods; In hardwoods, triterpenes and sterols are dominant (Adamová et al., 2020).

The main emission in softwoods comes from terpenes. These terpenes are constantly spread from wood and during the processing of wood (Çolak, 2002; Pohleven et al., 2019). The most important ones among these are natural compounds such as a-pinene, b-pinene, camphene, limonene, b-mirocene, a-terpinol and the compounds formed as a result of the reaction of monoterpenes such as phenicylalcohol, borneol, campphone, verbenone with water or oxygen (Çolak, 2002). Softwood releases large amounts of VOCs, most of which are terpenes. However, the same VOCs originating from hardwood can be released from the softwood as the wood texture can undergo thermal degradation during drying of the softwood (Otwell et al., 2000).

In general, hardwoods contain higher non-volatile terpenes, except for some tropical species, including monoterpenes and sesquiterpenes. In addition to acetic acid, hardwoods emit a wide variety of carbonyl compounds (aldehydes, carboxylic acids and ketones) and alcohols, especially aldehyde hexanal and pentanal. Acetic acid emission, hardwoods have more acetic acid emission than softwoods, as hardwood hemicelluloses contain higher amounts of acetyl groups. Hexanal is the dominant emission (Pohleven et al., 2019).

Drying type: Drying under natural conditions or artificially changes the profile of VOCs emitted from wood. Because as the temperature of wood rises and dries, VOC emission occurs in different ways (evaporation, steam distillation and thermal decomposition) (Wilson and Sakimoto, 2007). For example, acetic acid is formed during the drying of wood by hydrolysis of the acetyl groups of hemicelluloses, and furfural is formed from wood xylose in a strong temperature-dependent reaction (Adamová et al., 2020).

Dryer: Dryers are normally heated directly with natural gas, but some dryers use sanding dust in a later process step. When wood dries in dryers at high temperatures, air emissions of particles and volatile organic compounds (VOCs) are released. The VOC emission during the drying process is also caused by the direct burning of sanding dust and wood (Wilson, 2010). The drying exhaust gas may contain substances formed by thermal decomposition of one or more components of wood (cellulose, ligrins, resins, and the like), various aldehydes and acids such as formaldehyde, acetaldehyde, acetic acid and acids. Some of these substances have a relatively low boiling point and are also volatile in steam (Schmidt, 1993).

Temperature and time: Sun et al. (2020) investigated the effect of time on the TVOC and VOC emissions of particleboards during the production stages. The longer the exposure time of the particleboards under all production conditions (density, thickness, resin content), the TVOC emission decreased. The higher density, thickness, and resin content of the particleboards resulted in higher TVOC emission concentration at each measurement time and showed a negative correlation on the TVOC emission level. Increased esters, aldehydes and ketones are most susceptible to change in production conditions. However, terpenes exhibited a positive increase in density and thickness, but a negative effect by increasing the resin content. This result showed that the terpene compounds in TVOC mostly originated from wood particles. 
He et al. (2012) stated that the emission of formaldehyde has been decreased consecutively due to heat treatment in the drying and hot pressing phase. He also stated that urea formaldehyde glue contains the lowest VOC unlike formaldehyde. He stated that wood particles have the highest VOC content. He reported that VOC and formaldehyde release during the drying and hot pressing stages showed a similar trend.

The release of volatile organic compounds (VOCs) during convective drying of particles at high temperature has been experimentally and theoretically investigated. The drying medium was determined as superheated steam with a pressure of two bars. Two different temperature levels of the drying environment, 160 and $180^{\circ} \mathrm{C}$, and two different materials, yellow pine and spruce, were used. It is noted that the major released components consist of various types of monoterpenes, with a-pinene predominant in each of the two materials. The amount released has shown that it depends on the drying temperature and the time of the drying process (Johansson and Rasmuson, 1998).

Ishikawa et al. (2009) dried 3 different veneer types at $140-180{ }^{\circ} \mathrm{C}$ and observed that VOC and aldehyde emissions increased with increasing temperature as a result of HPLC, GS / MS analysis. He also stated that longer drying time was realized for the species with high moisture content and this increased the emissions.

Murata et al. (2013) aimed to reduce the formaldehyde emission released from plywood without using any chemicals. After the veneers with a humidity of $6 \%$ are dried up to $130^{\circ} \mathrm{C}, 3$-layer plywood is produced by heat treatment. Drying temperatures are determined as 130-150-170-190 ${ }^{\circ} \mathrm{C}$. It has been shown that heating the veneer layers in the temperature range of 150 to $170{ }^{\circ} \mathrm{C}$ effectively reduces the formaldehyde emission of the plywood without reducing the mechanical properties of the pavement. When the coating layers were heated in the temperature range of $150^{\circ} \mathrm{C}$ to $170^{\circ} \mathrm{C}$, the amount of hydrated water (monomolecular layer) was slightly reduced and the amount of dissolved water (polymolecular layer) remained unchanged. It is assumed that the formaldehyde emission of plywood is related to the state of the adsorption zone of the wood..

\section{HEALTH AND ENVIRONMENTAL EFFECT OF VOC}

In certain conditions, inhabitants of poorly ventilated buildings are more prone to suffer from "sick building syndrome" (SBS), which is a phenomen on characterized by various symptoms such as headache; eye, nose, or throat irritations; drycough; allergy reactions; dry and itching skin; non specific hypersensitivity; insomnia; dizziness and nausea or difficulty in concentrating; andtiredness. The intense odors may have a negative psychological influence as well (Adamová et al., 2020). In addition, when VOCs such as monoterpene emit together with NO2 and SO2, they contribute to acid accumulation and soil acidification (Granström, 2005)

Different TVOC definitions used by different countries make interlaboratory comparisons difficult. As shown in Table 4, there are a number of limits given by different regulations and specifications.

Table 4. Limit values after 28 days emissions testing in a ventilated test chamber required by various regulations across Europe and proposed by the WHO (Da Silva, 2017).

\begin{tabular}{|c|c|c|c|c|}
\hline \multicolumn{2}{|c|}{ Organisation/Institute } & $\begin{array}{l}\text { TVOC } \\
\left(\mu \mathrm{g} / \mathrm{m}^{3}\right)\end{array}$ & $\begin{array}{c}\text { Formaldehyde } \\
\left(\mu \mathrm{g} / \mathrm{m}^{3}\right)\end{array}$ & Product/Standard \\
\hline \multicolumn{2}{|l|}{ WHO } & - & 100 & \\
\hline \multicolumn{2}{|l|}{ Belgian regulation } & 100 or $1^{*}$ & 100 & $\begin{array}{c}\text { Construction products } \\
\text { CEN/TS } 16516\end{array}$ \\
\hline \multicolumn{2}{|c|}{ AgBB/DIBt (Germany) } & 1000 or $1^{*}$ & 100 & $\begin{array}{c}\text { Constructions products } \\
\text { CEN/TS } 16516 \text { and ISO } \\
16000\end{array}$ \\
\hline \multirow{3}{*}{$\begin{array}{l}\text { EMICODE } \\
\text { (Germany) }\end{array}$} & $\mathrm{EC1}^{\mathrm{PLUS}}$ & $\leq 60$ or $1^{*}$ & $50^{\mathrm{a}}$ & \multirow{3}{*}{$\begin{array}{r}\text { Flooring products } \\
\text { CEN/TS } 16516\end{array}$} \\
\hline & $\mathrm{EC} 1$ & 100 or $1^{*}$ & $50^{\mathrm{a}}$ & \\
\hline & $\mathrm{EC} 2$ & 300 or $1^{*}$ & $50^{\mathrm{a}}$ & \\
\hline \multirow{4}{*}{ France regulation } & ${\text { Class } \mathrm{A}^{+}}$ & 1000 & 10 & \multirow{4}{*}{$\begin{array}{l}\text { Construction products } \\
\text { ISO } 16000\end{array}$} \\
\hline & Class A & 1500 & 60 & \\
\hline & Class B & 2000 & 120 & \\
\hline & Class C & $>2000$ & $>120$ & \\
\hline \multirow{2}{*}{$\begin{array}{l}\text { Indoor air } \\
\text { comfort- } \\
\text { Eurofins }\end{array}$} & Standard & 1000 or $1^{*}$ & 60 & \multirow[b]{2}{*}{-} \\
\hline & Gold & 750 or $1^{*}$ & 10 & \\
\hline
\end{tabular}

The Construction Product Regulation (EU 2011/305) since 1st July 2013 defines the essential requirements for construction materials. This Regulation replaces the directive 89/106/EEC. Among the seven requirements number three, already present in the old directive, is dedicated to: hygiene, health and environment. Then the regulation prescribes that any construction work shall not be harmful to the health of occupants, meaning that no dangerous particles or gases shall be emitted in the air. The purpose of this regulation is to harmonize the technical and healthy description of products including also indoor emissions thus facilitating their marketing in the EU area. The goal is that the CE label applied on building materials and products will contain performance classes that cover all national regulations in Europe. Then each EU member state can specify which performance classes a product shall fulfil for being accepted on that national market. For indoor emissions and other types of releases, CEN has established a technical committee (TC 351) to undertake the work of developing the harmonised standards. A specific working group (WG 2) is dealing with indoor air. At the moment, WG2 has produced a test method (CEN/TS 16516) for indoor emissions based on the ISO 16000 series of standards concerning determination of emissions of VOCs from building products (Bulian ve Fragasa, 2016).

Considering instrumental methods used to determine the VOCs, gas chromatography-mass spectrometry (GC-MS) is commonly used to separate and identify the volatiles. For formaldehyde determination, 
liquid or gas chromatography is used, often after derivatization (Adamová et al., 2020).

\section{CONCLUSION}

Wood-based panels (plywood, fiberboard, particle board and OSB) widely used in the world were produced 400 million $\mathrm{m}^{3}$ in 2018 . These panels are widely used in the construction, decoration and flooring of homes, offices, schools as well as other non-industrial workplaces. During the production of all the panels, there is a drying process in which water is removed from the wood. VOCs formed during the drying process cause low air quality and therefore various disturbances. This review will make it easier to understand the factors affecting VOCs from wood during drying.

Different methods are used to prevent VOC emission from wood-based panels, which causes additional costs. More studies should be done on the temperature and time affecting the $\mathrm{VOC}$ in the drying process and a mathematical model should be created.

\section{ACKNOWLEDGMENTS}

This study was presented in ORENKO 2020 held by Karadeniz Technical University, Trabzon.

\section{REFERENCES}

Adamová, T., Hradecký, J. \& Pánek, M. (2020). Volatile organic compounds (VOCs) from wood and woodbased panels: Methods for evaluation, potential health risks, and mitigation. Polymers, 12(10), 2289.

Akbulut, T., Göker, Y. \& Ayrılmış, N. (2002). Using OSB panels instead of plywood. Journal of the Faculty of Forestry Istanbul University, 52(1), 65-79.

Altinok, M., Küreli, İ. \& Serbes, T. (2009). The determination of the effect to some physical and mechanical properties of wood material of vacuum and conventional drying. Journal of Polytechnic, 12(4), 271-278.

Aydin, I. \& Colakoglu, G. (2005). Formaldehyde emission, surface roughness, and some properties of plywood as function of veneer drying temperature. Drying Technology, 23(5), 1107-1117.

Baner.jee, S., Hutten, M., Su, W., Otwell, L. \& Newton, L. (1995). Release of water and volatile organics from wood drying. Environmental Science \& Technology, 29(4), 1135-1136.

Bilgin, U. (2019). Utilization of bark and husk extracts as filling in the production of plywood. Master's thesis, Karadeniz Technical University, Turkey.

Böhm, M., Salem, M.Z. \& Srba, J. (2012). Formaldehyde emission monitoring from a variety of solid wood, plywood, blockboard and flooring products manufactured for building and furnishing materials. Journal of Hazardous Materials, 221, 68-79.
Bulian, F. \& Fragassa, C. (2016). VOC emissions from wood products and furniture: A survey about legislation, standards and measures referred to different materials. Fme Transactions, 44(4), 358364.

Burn, J., Henk, J. \& Bloemen, T. (Eds.). (1993). Chemistry and analysis of volatile organic compounds in the environment. Blackie Academic \& Professional.

Çakmak, F. (2018). Investigation of technological characteristics of oriented strand boards (OSB). Master's thesis, Hacettepe University, Turkey.

Çolak, S. (2002). The Effect of impregnation procedure at plywood on technological properites, formaldehyde and acid emission of plywood. Ph.D. Thesis, Karadeniz Technical University, Turkey.

Çolakoğlu, G. (2004). Layered wood material lecture notes. K.T.Ü. Faculty of Forestry, Trabzon.

Çolakoğlu, G., Aydın, I. \& Çolak, S. (2002). The effects of waiting time of alder (Alnus glutinosa subsp. barbata) veneers before drying on shear and bending strength of plywood. Holz als Roh-und Werkstoff, 60(2), 127-129.

Da Silva, C.F.F.P. (2017). Interactions between volatile organic compounds and natural building materials. Ph.D. Thesis, University of Bath, England.

Eroğlu, H. \& Usta, M. (2000). Fiberboard production technology. KT.Ü. Faculty of Forestry Publication, $(200 / 30)$

Food and Agriculture Organization of the United Nations. (2018). Global Forest Facts and Figures, http://www.fao.org/3/ca7415en/ca7415en.pdf.

Granström, K. (2005). Emissions of volatile organic compounds from wood (Doctoral dissertation).

Ishikawa, A., Ohira, T., Miyamoto, K., Inoue, A. \& Ohkoshi, M. (2009). Emission of volatile organic compounds during drying of veneer: Red meranti (Shorea sect. Rubroshorea), larch (Larix sp.), and sugi (Cryptomeria japonica D. Don). Bull. Forestry Forest Prod. Res. Inst, 8(2), 115-125.

Johansson, A. \& Rasmuson, A. (1998). The release of monoterpenes during convective drying of wood chips. Drying Technology, 16(7), 1395-1428.

Doğan, K. (2015). The effect on some properties of oriented strand board (OSB) of ureaformaldehyde resin different melamine containing and density differences. Master Thesis, Kastamonu University, Turkey.

Murata, K., Watanabe, Y. \& Nakano, T. (2013). Effect of thermal treatment of veneer on formaldehyde emission of poplar plywood. Materials, 6(2), 410420.

Kara, O., Şahin, Ö., Bekar, İ. \& Kayacan, B. (2019). International Competitiveness Analysis Of Industrial Wood And Wood Products Sector: The Case Of Turkey. The International Journal of Economic and Social Research, 15(1), 15-32.

Otwell, L.P., Hittmeier, M.E., Hooda, U., Yan, H., Su, W. \& Banerjee, S. (2000). HAPs release from wood drying. Environmental Science \& Technology, 34(11), 2280-2283. 
Önem, B. (2018). Determination some factors affecting value of deviation from plane in the production of MDFLAM. Ph.D. Thesis, Kastamonu University, Turkey.

Özen, R. \& Kalaycioğlu, H. (2008). Particleboard industry lecture notes. Faculty of Forestry, Forest Industry Engineering Department, K.T.Ü. Trabzon.

Pohleven, J., Burnard, M.D. \& Kutnar, A. (2019). Volatile organic compounds emitted from untreated and thermally modified wood-a review. Wood and Fiber Science, 51(3), 231-254.

Rowell, R.M. (2005). Chapter 4: Handbook of wood chemistry and wood composites. CRC press.

Schmidt, A. (1993). U.S. Patent No. 5,263,266. Washington, DC: U.S. Patent and Trademark Office.

Stefanowski, B.K. (2018). Improving Indoor Air Quality (IAQ) Through Novel Wood-based Panel Modifications. Ph.D. Thesis, Bangor University, Wales.

Sun, S., Zhao, Z. \& Shen, J. (2020). Effects of the manufacturing conditions on the VOCs emissions of particleboard. BioResources, 15(1), 1074-1084.

Şahin, F.(2018). Evaluation of rice husks in manufacture of particleboard. Ph.D. Thesis, Kastamonu University, Turkey.

Velic, A., Soldán, M., Ház, A., Šurina, I. \& Jablonský, M. (2019). Determination of volatile organic compounds emissions from wood processing. Wood Research, 64(3), 461-470.

Walker, J. C. (2006). Primary wood processing: principles and practice. Springer Science \& Business Media.

Web-1:

https://www.google.com/search?q=free+and+bound $+\quad$ water+in+cell+wall\&tbm $=\quad$ isch $\& v e d=2 a h$ UKEwi76OfTxq7sAhUNixoKHXssDd4Q2-
cCegQIABAA\&oq= free

+and+bound+water+in+cell+wall\&-

gs_lcp=CgNpbWcQAzoECAAQHjoGCAAQCB

AeUJ9GWLZhYO1iaABwAHgAgAGMAYgBnwy

SAQQwLjEzmAEAoAEBqgELZ

3dzLXdpei1 pbWfAAQE\&sclient=img\&ei=fAiEX7

u6D42WavvYtPAN\&bih $=600 \& \quad$ biw $=\quad 1360 \#$ imgrc $=$ pcfp-bP0gEl-gM. Access Date: 10 September 2020 .

Web-2:

https://webdosya.csb.gov.tr/db/sanayihavarehberi/ice rikler//01_agac-urunler--uret-m--

20200103075113.pdf. Access Date: 10 September 2020.

Wilson, J.B. (2010). Life-cycle inventory of particleboard in terms of resources, emissions, energy and carbon. Wood and Fiber Science, 42, 90-106.

Wilson, J.B. \& Sakimoto, E.T. (2007). Gate-to-gate lifecycle inventory of softwood plywood production. Wood and Fiber Science, 37, 58-73.

World Health Organization. (2010). WHO guidelines for indoor air quality selected pollutants. The WHO European Centre for Environment and Health, Bonn Office.

Yu, C. W.F. \& Kim, J.T. (2010). Building pathology, investigation of sick buildings VOC emissions. Indoor and Built Environment, 19(1), 30-39.

Zengin, H. (2009). Problems and Solutions on Providing Wood Raw Material in Sheet and Plate Chip Industries. Master Thesis, İstanbul University, Turkey. 